\title{
GMOs: building the future on the basis of past experience
}

\author{
LUIZ F.L. REIS ${ }^{1}$, MARIE-ANNE VAN SLUYS ${ }^{2}$, RICHARD C. GARRATT ${ }^{3}$, \\ HUMBERTO M. PEREIRA ${ }^{3}$ and MAURO M. TEIXEIRA ${ }^{4}$ \\ ${ }^{1}$ Ludwig Institute for Cancer Research \\ Rua Professor Antonio Prudente 109, $4^{\circ}$ andar, 01509-010 São Paulo, SP, Brasil \\ ${ }^{2}$ Departamento de Botânica, Universidade de São Paulo \\ Rua do Matão 277, Cidade Universitária, 05509-900 São Paulo, SP, Brasil \\ ${ }^{3}$ Instituto de Física de São Carlos, Universidade de São Paulo \\ Av. Trabalhador São-Carlense 400, Centro, 13560-250 São Carlos SP, Brasil \\ ${ }^{4}$ Departamento de Bioquímica e Imunologia, ICB, Universidade Federal de Minas Gerais \\ Av. Antonio Carlos 6627, Pampulha, 31270-901 Belo Horizonte, MG, Brasil \\ Manuscript received on August 29, 2006; accepted for publication on October 24, 2006; \\ presented by LUCIA MENDONÇA PREVIATO
}

\begin{abstract}
Biosafety of genetically modified organisms (GMOs) and their derivatives is still a major topic in the agenda of government and societies worldwide. The aim of this review is to bring into light that data that supported the decision taken back in 1998 as an exercise to stimulate criticism from the scientific community for upcoming discussions and to avoid emotional and senseless arguments that could jeopardize future development in the field. It must be emphasized that Roundup Ready ${ }^{\circledR}$ soybean is just one example of how biotechnology can bring in significant advances for society, not only through increased productivity, but also with beneficial environmental impact, thereby allowing more rational use of agricultural pesticides for improvement of the soil conditions. The adoption of agricultural practices with higher yield will also allow better distribution of income among small farmers. New species of genetically modified plants will soon be available and society should be capable of making decisions in an objective and well-informed manner, through collegiate bodies that are qualified in all aspects of biosafety and environmental impact.
\end{abstract}

Key words: biosafety, genetically modified organisms, transgene.

\section{INTRODUCTION}

Agriculture has a fundamental role in significantly reduce the problem of hunger in the world, since it is a major challenge faced by modern society considering a population estimated in approximately 9 billion individuals by the year 2050 (World Population to 2003-2004). Preserving the environment is another great challenge facing society so that agriculture can continue to produce adequate and qual-

Correspondence to: Luiz F.L. Reis

E-mail: 1reis@ludwig.org.br ity food and fiber at the same time that a desirable reduction in the substitution of natural vegetation by cultivated areas is achieved. On the top of these issues, agricultural activity is, for the majority of developing countries, the largest source of foreign exchange as well as one of the largest employers. It has been estimated that, in 2010, agriculture will employ near three billion workers, corresponding to $50 \%$ of the population of these countries (James 2002). In Brazil, agricultural and livestock activities were responsible for revenues of 300 billion Reais 
in 2004, according to IBGE.

There is no doubt that the only way out for the dilemma of environmental preservation versus agricultural production is to increase productivity through the introduction of modern technologies that will generate products with greater aggregated value, greater yield and productivity, with lower environmental impact. In this context, technological development has an important role in the future of agricultural and livestock-rearing activities and must be a priority for the policies of social development and inclusion.

For the last three decades, the scientific community acquired significant knowledge and understanding of the methodologies involving the socalled "genetic engineering", in which well characterized fragments of DNA from a given organism can be manipulated in the laboratory and reintroduced into a second organism from a species that is different from the initial donor. The recipient organism becomes designated as transgenic or genetically modified organism, since it now harbors in its genomic new and known DNA sequences that makes it unique among members of the same species. This DNA fragment that was transferred between two species is called recombinant DNA.

The great advance that this methodology provides can be evaluated through the large-scale production of various drugs utilized in modern medicine that, before genetic engineering, were not available on an industrial scale. The first of these drugs, Interferon, is responsible for curing thousands of patients with leukemia or hepatitis (Kirkwood 2002). Without the technology of recombinant DNA, drugs like Interferon, Insulin, Growth Hormone and Erythropoietin, among others, would not have contributed enormously to improving the quality of life of and curing patients with cancer and diabetes, and several other pathologies. Without the technology of recombinant DNA, there would be no ways of supplying the world market with products that have the quality that GMO derivatives have.

But if, on the one hand, society was capable of accepting the medicines derived from GMO, in the case of genetically modified plants, a longer route was taken. Over recent years, we observed an inflamed debate about the introduction of GMOs into the food chain. This discussion, although absolutely necessary for defining the rules that such products must obey, has been conducted in an unproductive manner where scientific aspects that should guide the rules and decisions related to biosafety matters were substituted by to political and ideological aspects.

In Brazil, the debate concerning the commercial release of Roundup Ready ${ }^{\circledR}$ soybeans extended for more than 6 years, since its approval for commercial activities by the National Technical Committee for Biosafety (CTNBio) back in 1998, until the approval by the National Congress of the new Biosafety Law with the Presidential sanction in March 2005. During these years, discussions were centered in non-scientific issues or, sometimes, on misquoted scientific data. Experiments in laboratory scale and field trials were prohibited, leading to stagnation of our capability to generate data on all GMO-related issues. During these years, scientifically sound data were neglected, questioned, but never otherwise proven to be wrong. At the end, we lost precious time and, now, soybean is considered safe on the bases of the knowledge that was available at the time of the first decision, 6 years ago.

The aim of this review is to bring into light that data that supported the decision taken back in 1998 as an exercise to stimulate criticism from the scientific community for upcoming version of GMOs and to avoid emotional and senseless discussion that could jeopardize future development in the field. It must be emphasized that Roundup Ready® soybean is just one example of how biotechnology can bring in significant advances for society, not only through increased productivity, but also with beneficial environmental impact, thereby allowing more rational use of agricultural pesticides for improvement of the soil conditions. The adoption of agricultural practices with higher yield will also allow better distribution of income among small farm- 
ers. New species of genetically modified plants will soon be on the agenda for discussions and society should be capable of making decisions in an objective and well-informed manner, through collegiate bodies that are qualified in all aspects of biosafety and environmental impact as the CTNBio, established by the new Biosafety Law 11105/05.

\section{THE ORIGIN AND CHARACTERISTICS OF THE SOYBEAN PLANT Glycine max}

The soybean plant (Glycine $\max$ ) is a true domesticate since in the absence of the human intervention this species would not exist. A genome duplication occurs in the evolution leading to an allo or auto tetraploid $(2 \mathrm{n}=40)$ that behaves as a diploid organism (Shoemaker et al. 1996). It belongs to the genus Glycine, subgenus soybean. In addition to Glycine max, this subgenus contains another two species: Glycine soja, which is the wild form of the soybean plant, and Glycine gracilis, which is the weed form (Lackey 1981).

The cultivation of soybeans by man as a source of food originates from the northern and central regions of China and it is considered one of the oldest oilseed cultivated by man. The accepted historical evidence suggests that soybeans were domesticated between the $17^{\text {th }}$ and $11^{\text {th }}$ centuries BC (Hymowitz 1970). In the Americas, soybeans were introduced in the year 1765, and were utilized as a fodder species. With the success of utilizing soybeans in the production of oil in Europe between the years 1900 and 1910, commercial interest in soybeans spread through the Americas. In Brazil, the first records of the introduction of soybeans date from 1882, in Bahia, by Gustavo Dutra.

The soybean plant (Glycine max) is essentially self-pollinating. The anthers mature in the bud and release the pollen inside the stigma of the same flower, thus ensuring a high degree of self-pollination (McGregor 1976, Carlson and Lersten 1987). In a crop field, the degree of cross-pollination between two plants located in adjacent rows is extremely low and several studies have shown that this percentage ranges between $0.03 \%$ and $3.62 \%$
(Woodworth 1922, Caviness 1996, Ahrent and Caviness 1994). For distances greater than 4.5 meters, the cross-pollination between two individuals falls to $0.02 \%$ and frequently is not detected. As demonstrated by Caviness (1970), bees are responsible for the rare cases of cross-pollination but, in the field, this mechanism has been shown to be inefficacious and, as a result, soybeans are considered to be a pure homozygous lineage.

Soybean cultivars are only sexually compatible with members of the genus Glycine and crosses between members of the subgenera only take place with intentional and appropriate technical intervention. On the other hand, soybean crosses are not even possible with relatives in other genera. In Brazil, the soybean plant is the only genus of Glycine, which makes its cross-pollination (or horizontal transmission of its genetic material to other species) impossible. This is proven by the fact that no plants of other species containing genetic material from soybeans have been detected, even considering the enormous areas of soybeans planted in Brazil and around the world. Another important observation is the fact that the soybean plant does not survive vegetatively outside of the crop fields and, once again, there are no reports of self-sown plants or feral populations growing in areas adjacent to the crop fields. For all these reasons, the discussion about the escape of the gene that confers tolerance to the herbicide glyphosate in Roundup Ready® soybeans, through sexual crosses, is not scientifically sustainable.

\section{THE RATIONALE FOR THE DEVELOPMENT OF ROUNDUP READY® SOYBEANS}

Roundup Ready soybean event 40-3-2 was produced by introduction of the glyphosate tolerant $\mathrm{cp} 4 \mathrm{ep}$ sps coding sequence derived from the common soil bacterium Agrobacterium sp. strain CP4 into the soybean genome using particle-acceleration transformation. The CP4 EPSPS protein is a member of the class of EPSPS proteins found ubiquitously in plants and microorganisms.

As mentioned above, the soybean plant is an 
exotic species, without wild relatives in the Americas, that reproduces by self-pollination and does not provide a risk of horizontal transmission of its genes. Thus, the development of transgenic soybeans that might represent greater aggregated value, either through gains in productivity or through greater nutritive value, would have the advantage of minimizing the risks of crosses between the genetically modified variety and other wild relatives.

The adoption of Roundup Ready® soybeans have a positive impact on present-day agriculture by (a) offering farmers a new option for controlling weeds through the use of a herbicide with a broad spectrum of action, (b) utilizing a herbicide with lower environmental impact, (c) allowing seasonlong control over weeds through the utilization of a herbicide for which there have been few reports of resistance over 30 years of utilization throughout the globe, (d) allowing the practice of direct planting (no-till), with benefits for the quality of the soil and reduction of erosion, and (e) being a system of relatively low cost, a benefit that favors the farmer.

\section{THE GENE aro A AND THE PROTEIN EPSPS}

The protein that is the target of the herbicide glyphosate is the enzyme named 3-phosphoshikimate 1-carboxyvinyltransferase or also 5-enolpyruvylshikimate-3-phosphate synthase (EPSP synthase), which will be referred to as EPSPS throughout this review.

EPSPS is an enzyme that is central to the shikimate pathway and essential for the production of aromatic amino acids in plants, bacteria, fungi, algae and parasites of the order Apicomplexa (Steinrucken and Amrhein 1980, Bentley 1990, Roberts et al. 1998). These amino acids are essential for protein synthesis, defense against insects, cell wall formation, synthesis of plastoquinones, etc (Duke 1988). The enzyme forms part of the small family of enolpyruvyl transferases, which are responsible for catalyzing the transfer reaction for the enolpyruvyl group. This family also includes UDP-N-acetylglucosamine enolpyruvyl transferase (MurA), which is important for the synthesis of the cell wall in bacteria (van Heijenoort et al. 1994). EPSPS catalyzes the sixth step in the synthesis of chorismate (the precursor of aromatic amino acids), from phosphoenolpyruvate and erythrose-4-phosphate, and is inhibited by the glyphosate-specific competitive inhibitor. Glyphosate presents little or no toxicity in animals exactly because of the absence of this enzyme in these species (Williams et al. 2000) (Figure 1).

The enzyme EPSPS has now been identified in basically all organisms in which there is evidence for the synthesis of the amino acid tryptophan. It is absent in animals, including humans, that depend on daily intake of these amino acids through the food diet (Kishore and Shah 1988, Roberts et al. 1998). The enzyme is encoded by a single gene called aro $\mathrm{A}$, in the majority of the organisms in which its activity has been characterized. There is a total of 127 entries with the gene name aroA in the databank Kyoto Encyclopedia of Genes and Genomes (Kegg 2004), relating to sequences deposited from different organisms for which the genome has been partially or fully sequenced.

To illustrate the degree of similarity between the EPSPS proteins, we discuss the similarity between the proteins in plants and bacteria. As well as the sequence of the EPSPS protein of soybeans found in the databank Soybean Genomics Initiative (SGI) (http://soybean.ccgb.umn.edu/), and the sequence corresponding to the protein of Arabidopsis thaliana, a plant model for the vegetal system (AGI 2000). For the bacteria, we selected the protein of Escherichia coli $\mathrm{K} 12$ and three deposited sequences corresponding to Agrobacterium tumefaciens. Two of these corresponded to genes identified in the two genome projects accomplished and the third sequence was deposited following work done by Harrison et al. (1996), with the transformation of soybeans that gave rise to Roundup Ready® soybeans. Table I illustrates the results obtained from aligning the EPSPS proteins sequenced in different organisms. As it can be observed, all the other alignments offer a similarity of less than 


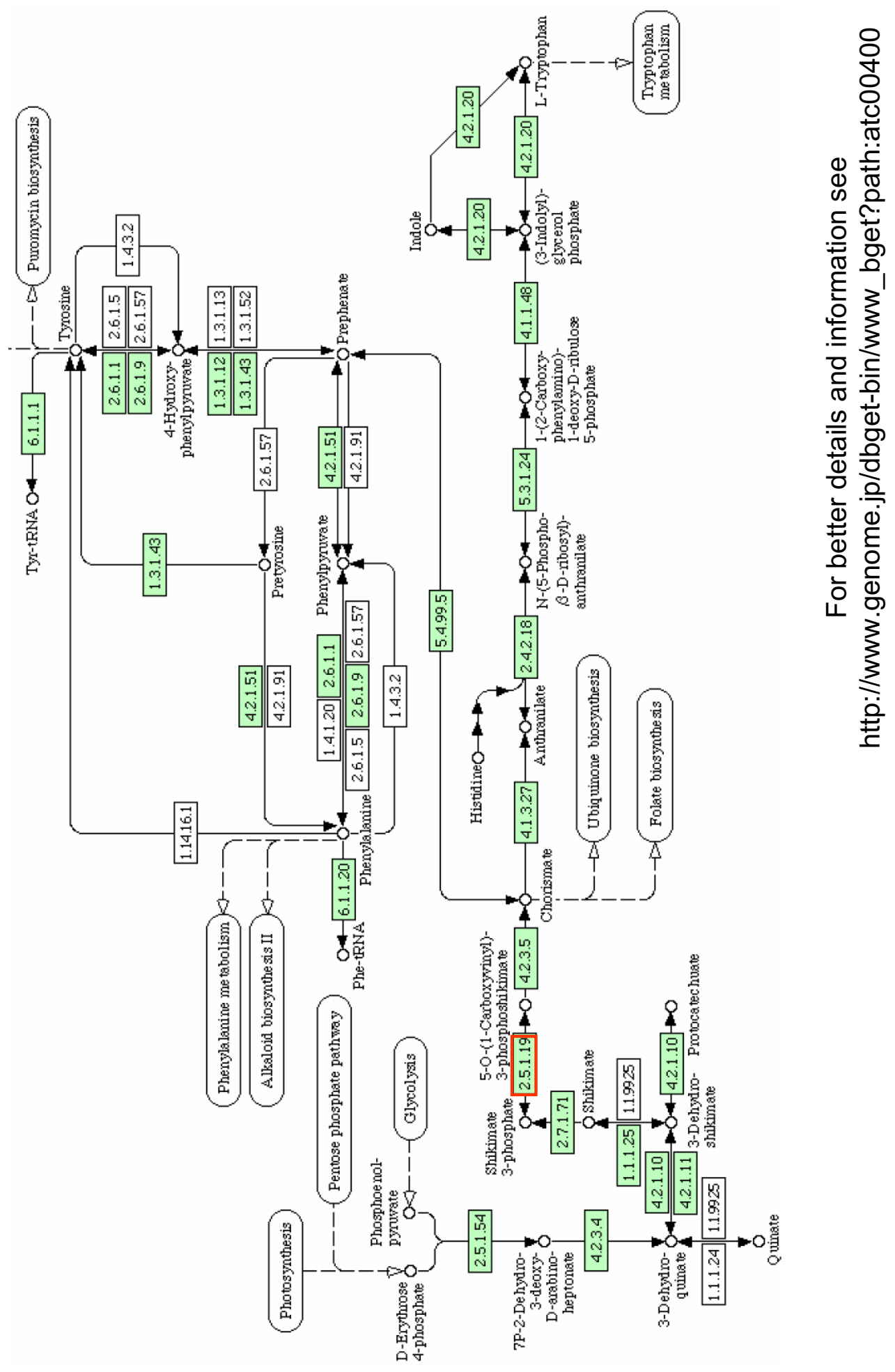

Fig. 1 - Synthesis of aromatic amino acids. Enzymatic activity of EPSPS is depicted in red. 
$70 \%$, with the exception of the comparison between plants (soybean and arabidopsis) and the two strains of $A$. tumefaciens that were completely sequenced (AGR_C_1140 and Atu0642). Independent of this fact, all proteins are associated with the same step on the biosynthesis route for chorismate and perform the same biological function. The EPSPS proteins of the bacterium (E. coli) and the plant (A. thaliana) present similarity of $68 \%$ and that, between the bacteria E. coli and Agrobacterium Q9R4E4, the similarity is $41 \%$.

Because of the similarity observed, we could develop a phylogenetic tree of EPSPS proteins, which is present in Figure 2. This protein is found in all domains of life, including bacteria, archaea and eukaryotes (plants, fungi and parasites of the Apicomplexa group). This indicates that its function is extremely important and that its origin is probably very ancient. However, the tree demonstrates that we have two distinct families of EPSPS proteins: one found in plants and some bacteria (including E. coli) and the other found in fungi, other bacteria (including the genus Agrobacterium) and archaea.

What also deserves attention is the fact that the Roundup Ready® soybeans were transformed using a gene that belongs to the first of these families, from the genus of the plant homologues (including soybeans). It is possible that the differences between the proteins of the two families may have resulted in the effect of tolerance to the glyphosate found in Roundup Ready ${ }^{\circledR}$ soybeans donor species Agrobaterium spp., despite maintaining the same function and structural similarity. Thus, it is possible that genes from fungi and archaea could also be used, resulting in similar phenotypes.

\section{OBTAINING THE GENETICALLY MODIFIED SOYBEAN LINEAGE}

To obtain a genetically modified plant lineage, the gene of interest needs to be mobilized within the genome of the plant, so that there is chromosome integration and perpetuation of the genetic information introduced, for subsequent generations. The first stage is to select the gene. Next, a biological vector needs to be used to ensure the maintenance of the integrity of the gene. (The vector maintains the integrity of the gene before the transformation). There are different ways of introducing a gene of interest into plants, and there is a wide range of literature available. The strategy adopted for obtaining the Roundup Ready® soybeans (Event 40-3-2) was the utilization of the method known as biobalistics, in which a particle accelerator is utilized that literally fires DNA molecules into the plant cell.

Preliminary work by Barry et al. (1992) indicated that, to obtain plants that were resistant to glyphosate, it would be necessary to introduce a gene encoding for a protein with high catalytic activity in the presence of glyphosate. Various tests were carried out in order to evaluate a variety of EPSPS isolated from different plants (Padgette et al. 1991, Ruff et al. 1991) with tolerance to glyphosate and also high affinity for its substrate. The EPSPS protein from Agrobacterium sp. strain CP4 was selected as the best isoform to fulfill these requisites (Padgette et al. 1995).

Thus, the gene cp4 epsps, which codes for the protein CP4 EPSPS of Agrobacterium tumefaciens strain CP4, was inserted into a vector called PV-GMGT04, which is represented in Figure 3 (Padgette et al. 1995). This vector is a plasmid derived from the plasmid pUC119, with a capacity to propagate only in bacteria. This plasmid has two copies of the cp4 epsps gene: one under the control of the promoter of the cauliflower mosaic virus and the other under the control of the promoter of the FMV virus (Figwort Mosaic Virus). The coding sequence of the protein CP4 EPSPS is preceded by the chloroplast transit peptide sequence (CTP4) derived from the petunia EPSPS, in the same reading window. The CTP sequence causes the CP4 EPSPS protein to be transported to the chloroplast, which is the localization site for this protein and where the synthesis of the aromatic amino acids takes place, with the cleaving of the functional protein just after entering the chloroplast. The sequence that is not translated from the nopaline synthase gene has a polyadenyla- 
TABLE I

Similarity among EPSPS (aroA).

\begin{tabular}{l|c}
\hline Organism and accession number of aminoacid sequence $^{1}$ & $\%$ of similarity \\
\hline A. thaliana At1g48860 e A. tumefaciens Atu0642 & $49 \%$ \\
\hline A. thaliana At1g48860 e A. tumefaciens CP4 & $40 \%$ \\
\hline A. thaliana At1g48860 e E. coli b0908 & $68 \%$ \\
\hline A. tumefaciens CP4 e E. coli b0908 & $46 \%$ \\
\hline A. tumefaciens Atu0642 e A. tumefaciens CP4 & $41 \%$ \\
\hline A. tumefaciens Atu0642 e E. coli b0908 & $51 \%$ \\
\hline A. tumefaciens_C AGR_C_1140 e A. tumefaciens Atu0642 & $100 \%$ \\
\hline
\end{tabular}

${ }^{1}$ Atu0642 (gi:17739000); At1g48860 (gi: 15221986); AGR_C_1140 (gi:15155591); e E. coli b0908 (gi:1787137) Agrobacterium CP4 (gi:8469107) was obtained from Harrison et al. (1996). Sequence from soybean was obtained from http://soybean.ccgb.umn.edu/. ${ }^{2}$ Similarity was determined by BLAST2Seq, http://www.ncbi.nlm.nih.gov/blast/bl2seq.

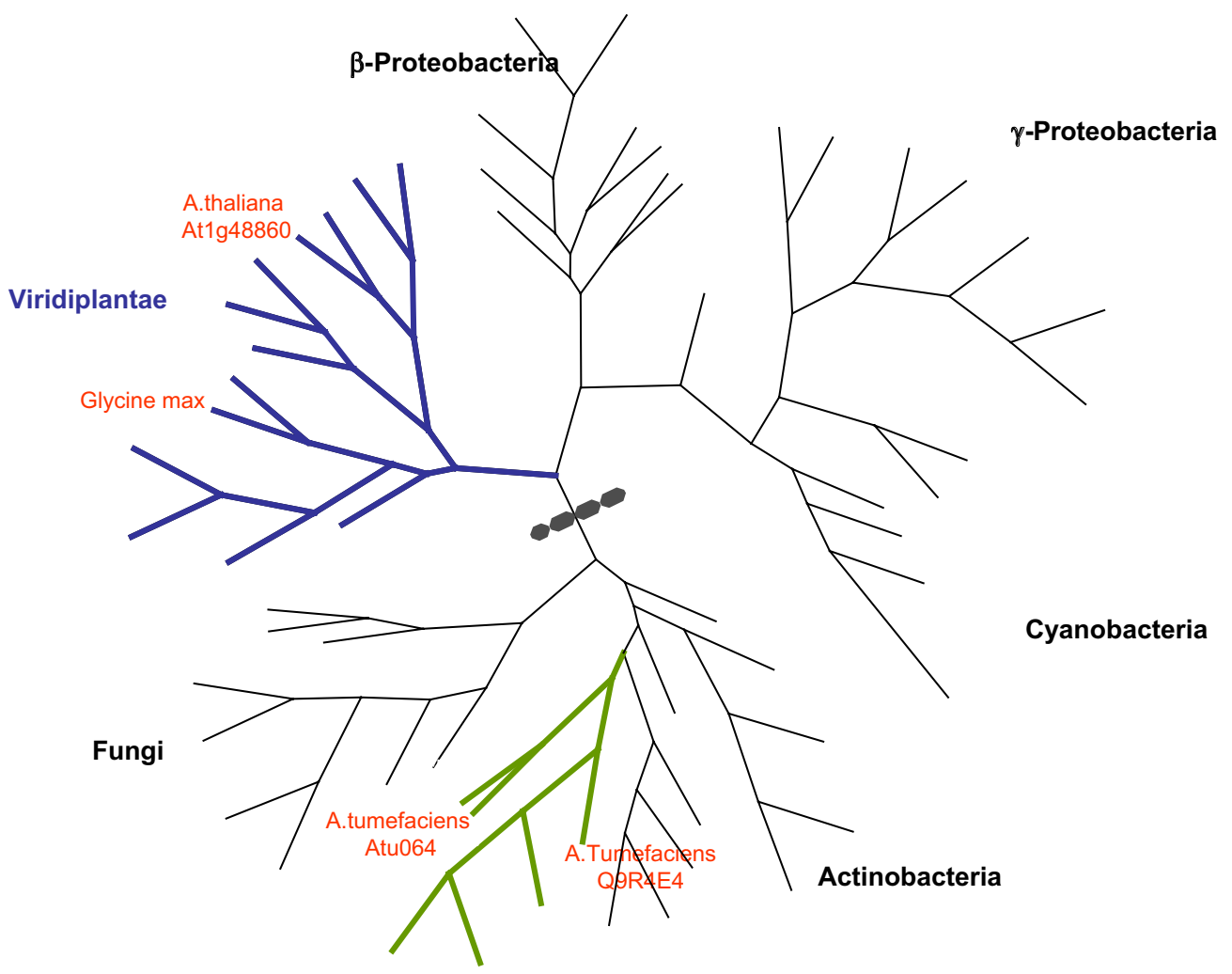

Archaea

Fig. 2 - Philogenetic tree based on sequence alignment of EPSPS. Doted green line represents the diversion between the two families. 
tion site, as well as the functional sequence of the cp4 epsps gene. In addition, the plasmid contains the transformation marker gene uidA, which confers the expression of the GUS protein and a blue color in the presence of an adequate substrate (Jefferson et al. 1987); the origin for bacterial replication (ori-pUC), which allows the propagation of the vector PV-GMGT04 in bacteria; and the selection marker gene nptII, which confers resistance to the antibiotic kanamycin, which is only active in bacteria.

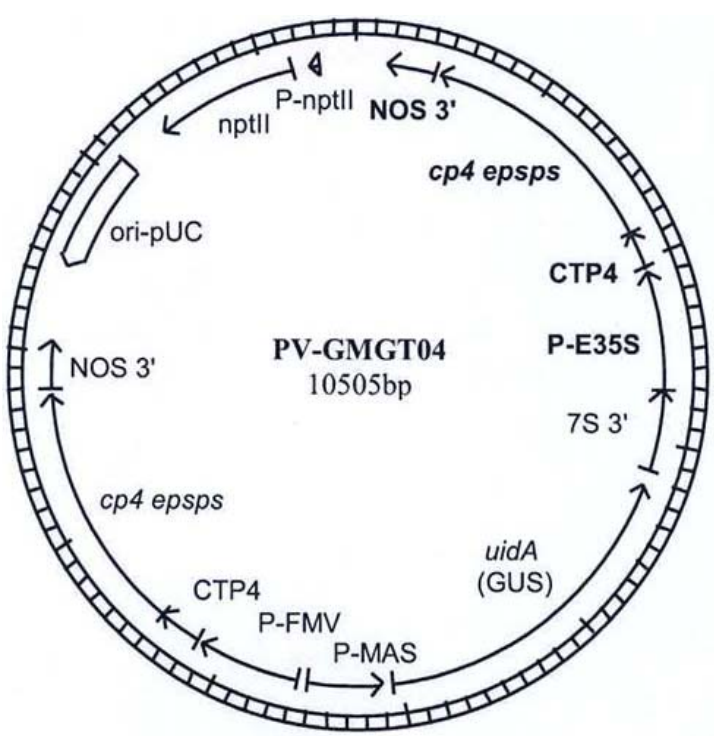

Fig. 3 - Schematic representation of plasmid PV-GMGT04: PE35S: Promoter/ enhancer from CaMV. CTP4: Signal peptide from Petunia hybrida. epsps protein cp4 epsps: EPSPS gene de Agrobacterium sp. Strain CP4. NOS 3': 3'UTR of nopaline synthase from Agrobacterium tumefaciens. P-nptII: promoter of nptII gene, from transposon Tn5. nptII: neomycin phosphotransferase, type II, from transposon Tn5. ori-pUC: origem of replication from pUC119. P-FMV: promoter of $35 S$ gene from FMV. P-MAS: promoter of Mannopine synthase gene from Agrobacterium tumefaciens. uidA: $\beta$-glucoronidase gene from $E$. coli, for GUS expression. 7S 3': 3' UTR of $\alpha$ sub-unit from soybean $\beta$-conglicinine gene.

The transformation event was performed by the process of bioballistics and the transformed plants were monitored for the appearance of the blue color as a result of the expression of the GUS protein. Thus, plants that have turned blue due to the presence of the uidA gene should also harbor the cp4 epsps gene from the A. tumefaciens strain CP4. This type of experimental approach avoids the use antibiotics as a selection system.

A total of 316 lineages of transgenic soybeans were generated by the transformation of the cultivar A5403. Fourteen lineages that expressed the GUS gene were selected and tested against different doses of glyphosate. One of these lineages, called $\mathrm{R}_{0} 40-3$, was shown to be resistant to glyphosate, with growth that was comparable to that of control plants, giving rise to lineages 40-3 12 and 40-3-2 (sic), which were tested in the field. While seven out of seven plants of the lineage 40-3-1 showed activity of the GUS gene, none of the ten plants of the lineage 40-3-2 that were tested showed activity of the GUS gene. In addition to this, the plants derived from the lineage 40-3-2 showed segregation for high resistance to glyphosate, suggesting that this lineage was homozygous for the transgene, without expressing the GUS protein.

The molecular characterization of the insertion site for the transgene in the event 40-3-2 showed that a single cassette of expression of the gene cp4 epsps was integrated into the genome of the cultivar A5403 (see detail in Figure 3) (Padgette et al. 1995). Subsequently, by sequencing the regions of the junction between the insert and the genomic DNA, Windels et al. (2001) showed that, at the junction with transgene promoting region, there were sequences of genomic soybean DNA immediately adjacent to the transgene. However, at the junction with the 3'non-translated region of the nos gene, there were rearrangements, with the presence of a truncated sequence of the gene cp4 epsps with 254 base pairs, followed by a DNA sequence with 534 base pairs without any known homologue, followed by the genomic soybean DNA. In Western Blot tests, the only protein containing sequences of CP4 EPSPS had a molecular weight of $46 \mathrm{kDa}$, which was expected for the mature and active form of CP4 EPSPS (Rogan et al. 1999). 


\section{THE THREE-DIMENSIONAL STRUCTURE OF THE ENZYME EPSPS}

The three-dimensional structure of EPSPS presents an unusual structure. While the majority of proteins of the $\alpha / \beta$ class (Levitt and Chothia 1976, Orengo et al. 1997) are composed of domains in which the $\beta$-sheets are predominantly buried inside the structure and the $\alpha$-helices are mainly arranged on the surface, in the case of EPSPS the distribution of the secondary structural elements is the opposite, forming an "inside-out $\alpha / \beta$ barrel" (Stallings et al. 1991). The single polypeptide chain curls to form two domains, each composed of three repetitions of the motif $\beta \alpha \beta \alpha \beta \beta$, thereby generating pseudosymmetrical third-order structure. The active site lies in the crease between the two domains, and is only completely formed after the bonding of the substrate shikimate-3-phosphate, which leads to a structural change in the enzyme that brings the domains together.

\section{STRUCTURAL ClassificATION}

Various classification systems exist for three-dimensional protein structures and their domains (Orengo et al. 1997, Murzin et al. 1995). The CATH system classifies protein structures by using a hierarchy in a way that is analogous to the system used by the Enzyme Commission for enzymatic activity. The higher levels of the classification initially follow the class of the protein $(\alpha, \beta, \alpha / \beta$, etc) and then its architecture, topology and homology. According to this system, the two domains of EPSPS can be classified as 3.65.10.10 $(\mathrm{C}(3)=\alpha / \beta ; \mathrm{A}(65)$ $=$ prism $\alpha / \beta ; \mathrm{T}(10)=$ UDP acetylglucosamine -1 carboxyvinyl-transferase; $\mathrm{H}(10)=$ transferases $)$.

\section{Catalyzed Reaction and Proposed Mechanism}

EPSPS catalyzes the transfer of the enolpyruvyl group from phosphoenolpyruvate (PEP) to the $5^{\text {th }}$ hydroxyl of shikimate-3-phosphate (S3P) (Figure 4), thus generating 5-enolpyruvyl-3-shikimate phosphate. Chemically speaking, this is a rare reaction, because it involves the cleavage of the $\mathrm{C}-\mathrm{O}$ bond of PEP rather than the high-energy bond (P-O), which is more common among enzymes that utilize PEP. It is believed that the bonding of S3P is the trigger that leads to the closing of the two domains, and that this is a prerequisite for the subsequent bonding of PEP. On the other hand, some recent studies have suggested that the bonding of the substrates is random (Gruys et al. 1992, 1993). The reaction proceeds via an addition-elimination mechanism and passes through the formation of an intermediary in which the C2 of PEP takes on a tetrahedral configuration and the $\mathrm{C} 3$ transforms into a methyl group (Walsh et al. 1996). Following this, the inorganic phosphate is eliminated from the intermediary and a proton is removed from $\mathrm{C} 3$, thus reestablishing the double bond between $\mathrm{C} 3$ and $\mathrm{C} 2$. The addition and elimination steps take place with opposing stereochemistry.

The determination of the crystallographic structure of the EPSPS of E. coli has allowed the identification of at least some of the residues of the active site that are responsible for the catalysis. The most recent evidence suggests that Lys22 is responsible for the removal of the proton from the 5-OH of $\mathrm{S} 3 \mathrm{P}$ and its transfer to $\mathrm{C} 3$ during the addition step, and that Asp313 acts as a base, accepting the proton back from $\mathrm{C} 3$ during the subsequent elimination. In addition to this, a series of other residues coating the cavity of the active site is responsible for the bonding of the S3P (Ser23, Arg27, Ser170, Ser169, Ser197, Asn336 and Lys340) and the PEP (Arg124, Arg344 and Arg386, Lys411 and Glu341). It is believed that this latter (Glu341) may be important in the process of releasing the product or the entry of the substrate.

\section{COMPARISON BETWEEN THE ENZYMES OF \\ E. coli, SOYBEANS AND Agrobacterium tumefaciens}

\section{Molecular Curling AND Surface}

Modeling techniques using homology (or comparative modeling) allow theoretical models to be drawn up for proteins that have not yet had their threedimensional models resolved by X-ray diffraction or nuclear magnetic resonance (Goldsmith-Fischman 
<smiles></smiles>

\section{Shikimate-3- phosphate}

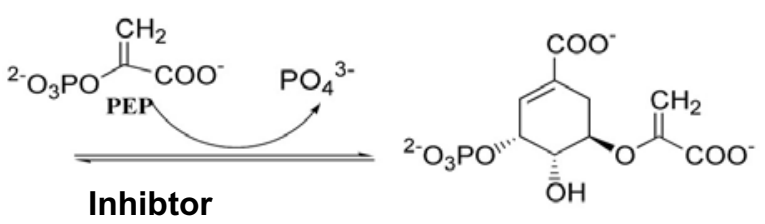

5-enolpyruvylshikimate-

3-phosphate (EPSP)

Fig. 4 - Catalytic reaction mediated by EPSPS and structure of the inhibitor (glyphosate).

and Honig 2003, Kopp and Schwede 2004, Chen and Pellequer 2004). At present, the only known structure from an EPSPS is the enzyme coming from $E$. coli, which is $26 \%$ sequentially identical with the CP4 EPSPS of Agrobacterium tumefaciens (Padgette et al. 1996b), thus allowing the construction of a hypothetical model of the latter. On the other hand, a comparison between the sequences of E. coli and soybeans shows that they are 55\% identical, with full conservation of all the important residues of the active site. For this reason, the structure of $E$. coli will be treated as representative of soybeans during the remainder of this discussion.

Figure 5 shows a comparison between the model for CP4 EPSPS, constructed by means of the application of spatial restrictions implemented in the ModelLer program (Sali and Blundell 1993), and the crystallographic structure of the EPSPS of E. coli. The curling is identical in the two cases but, because of a series of insertions in the sequence of CP4 EPSPS, in relation to E. coli (CP4 EPSPS has a total of 455 residues, whereas E. coli has 427), the former presents some loops protruding on the surface of the structure (Figure 5D). Because of the deficiencies in the process of modeling by homology in cases of low sequential identicalness like this, such regions are subject to relatively large errors in the positions of atoms and must be interpreted with caution. However, in this specific case, these regions do not affect the active site and the residues responsible for the tolerance to glyphosate that will be our main focus of interest.
The topography of the surface of the two enzymes is similar, but not identical (Figures 5B and $\mathrm{D})$, as is the charge distribution, demonstrated by the map of electrostatic potential. In qualitative terms, the differences observed are of the expected order of magnitude for two distant homologues enzymes that share only $26 \%$ of their sequential identity.

\section{Structural BASIS FOR TOLERANCE OF GLYPHOSATE}

Schönbrunn et al. (2001) described the crystallographic structure of the ternary complex between the EPSPS of E. coli, S3P and glyphosate, presenting data that were coherent with previous nuclear magnetic resonance studies (McDowell et al. 1996a, b). The E. coli enzyme is susceptible to glyphosate and the inhibitor occupies the expected site for the bonding of PEP that is cited above (Kim et al. 1996), with its phosphonate group stabilized via electrostatic interactions and hydrogen bonds with the side chains of Gln171, Arg124, Lys22 and Lys411, and also the amine group of Gly96. The carboxylic acid group, in its turn, interacts with Lys22, Arg386 and Arg344 (Figure 6A).

The distance between the anionic centers of the PEP is less than in the case of glyphosate, because of its chemical structure (Figure 5). The authors suggest that the $E$. coli enzyme is capable of bonding both the substrate and the inhibitor, because of the conformational flexibility of the residues that form the site of bonding to the phospho- 


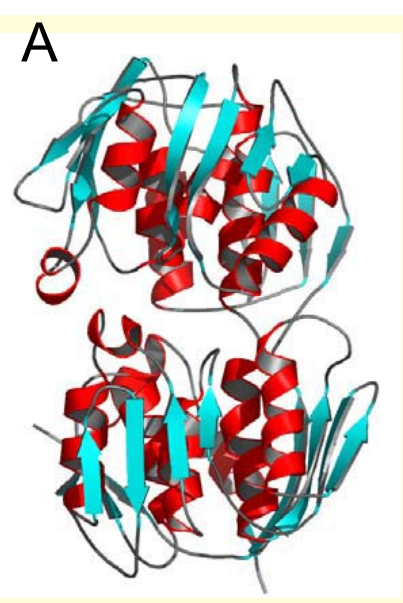

C
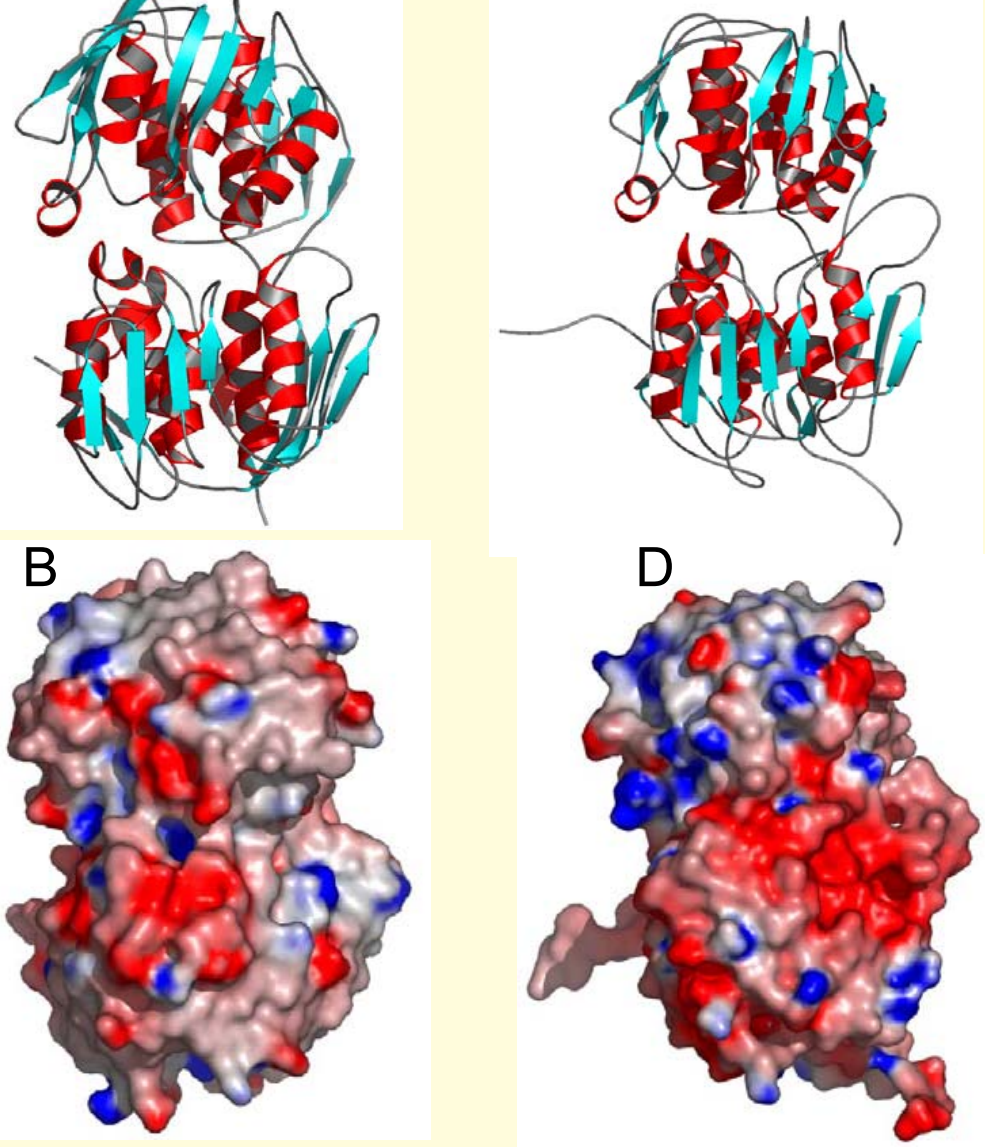

Fig. 5 - Ribbon (A) and electrostatic (B) representations of crystal sctructure of E.coli EPSPS. Regions with negative positive potentials are in red and blue, respectively. In (C) e (D) we have the same representations for Agrobacterium tumefaciens CP4 EPSPS.
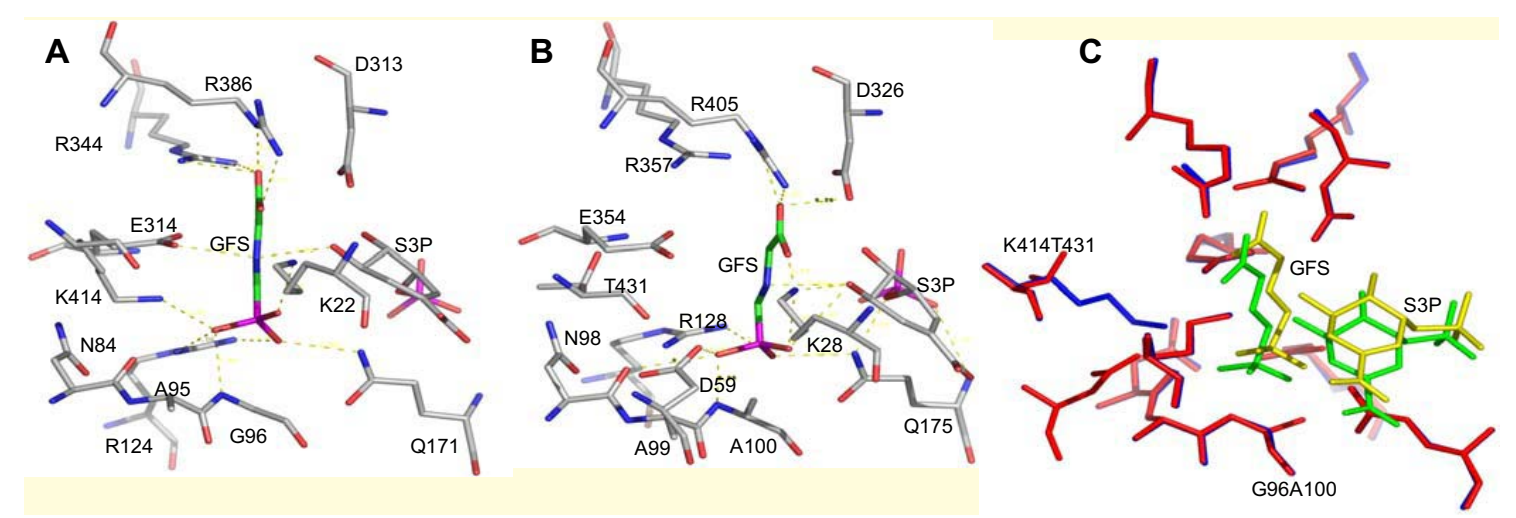

Fig. 6 - Interaction between glyphosate and E.coli EPSPS (A), or CP4 EPSPS (B). In (C) the two models are superimposed with glyphosate e shikimate-3-phosphate depicted in green (E.coli) and yellow (CP4 EPSPS). 
nate. This proposal also explains the tolerance towards glyphosate that is observed in some species and mutations of EPSPS. Specifically, the substitution of Gly96 by alanine in position 100 of CP4 EPSPS would lead to a steric impediment between the methyl group of the alanine and the phosphonate group of the glyphosate, thus reducing its affinity. On the other hand, as it is a smaller molecule, the bonding of the PEP substrate ought not to be harmed, since its phosphate group would occupy a site further away from Ala100. Figure 6B shows and attempt to model glyphosate at the active site of CP4 EPSPS. The presence of the methyl group of Ala100 obliges the glyphosate to move upwards in the hypothetical model, but in practice this would be unviable because it would cause steric impediments with other regions of the active site. This movement is more evident in Figure 6C, in which the structures of the CP4 EPSPS and E. coli enzymes are compared.

Today, it is believed that the presence of Ala100 is the main cause of tolerance towards glyphosate in some species, including Agrobacterium tumefaciens strain CP4. On the other hand, the soybean enzyme, like $E$. coli, is susceptible to the agrotoxin exactly because it has a glycine in the homologous position (Padgette et al. 1996a).

Interestingly, the CP4 EPSPS model shows a second difference in the region of the active site, in comparison with E. coli. Lys411 was replaced by Thr431 in CP4 EPSPS, thus leading to the loss of an electrostatic interaction between the enzyme and the phosphonate of the inhibitor (Fig. 6B). At present, the importance of this observation is unknown, but it may represent part of the explanation of why CP4 EPSPS retains a high affinity for PEP and low affinity for glyphosate, while the simple Gly96Ala substitutions in E. coli and Petunia reduced the affinity of both of them, albeit to different degrees (Padgette et al. 1991, Barry et al. 1992). For example, the $\mathrm{K}_{\text {app }}[\mathrm{PEP}]$ in the case of CP4 EPSPS is $12 \mu \mathrm{M}$ and the $\mathrm{K}_{\mathrm{i}}$ [glyphosate] is $2.72 \mathrm{mM}$, giving a value of $K_{i} / K_{\text {app }}=227$. The analogous value of $K_{\mathrm{i}} / \mathrm{K}_{\mathrm{app}}$ for the mutant enzyme Gly101Ala of Petunia is only 10, thus indicating lower selectivity between inhibitor and substrate. Nonetheless, the simple mutant still demonstrates a good degree of selectivity, since the $\mathrm{K}_{\mathrm{i}} / \mathrm{K}_{\mathrm{app}}$ for the wild enzyme is only 0.08. An excellent review of this subject is given by Padgette et al. (1996a).

\section{RISKS OF ALLERGENICITY ON THE BASIS OF STRUCTURE SIMILARITY TO KNOWN ALLERGENS}

Allergies are adverse reactions set up by the individual's immune system in response to exposure to a chemical agent that normally is inoffensive. They affect around $1-2 \%$ of the adult population (Anderson 1996). In the case of foods, this response is generally triggered by proteins present in the food. The most common type of allergy to foods is mediated by antibodies of the class $\operatorname{IgE}$ that are specific for the allergen, but a great diversity of other immunological reactions may also be involved, including delayed hypersensitivity (Sampson and Burks 1996, Mekori 1996). When interacting with antibodies of IgE type on the surface of mast cells and basophils, the allergen triggers the release of mediators for the allergic reaction, thus provoking reactions that range from slight skin or intestinal symptoms to anaphylactic shock. In the case of genetically modified foods, there is therefore a need to assess the risks to the organism that are associated with the expression of a non-native protein and, particularly, the possibility that this protein could trigger an allergenic response in the consumer.

\section{Previous STUdies}

In 1996, the International Food Biotechnology Council and the Allergy and Immunology Institute of the Life Science Institute proposed an approach based on a decision tree for evaluating the allergenic potential of heterologous proteins present in genetically modified foods (Metcalfe et al. 1996). This proposal was subsequently modified in 2000, by the Joint FAO/WHO Consultation on Safety Aspects of Genetically Modified Foods of Plant Origin and again in 2001 by the same commission. The 
FAO/WHO decision tree of 2001 involves a series of steps, starting with a theoretical analysis of the amino acid sequence of the protein and its comparison with known allergens.

The use of the FASTA program or an equivalent is recommended (Pearson 2000) for aligning the protein of interest (CP4 EPSPS in the case of the Roundup Ready® soybeans against a databank of allergens. The suspicion of possible allergenicity must be raised if (1) the protein is more than $35 \%$ sequentially identical with a known allergen, within a window of 80 residues, or (2) there is at least one stretch of six contiguous identical residues (Becker 2001). However, it is recognized that this methodology merely represents the best approach possible in the light of the present knowledge of the subject. Despite being efficacious in identifying the probable risks associated with linear epitopes, this approach comes up against difficulties in predicting conformational epitopes that depend on the tertiary structure of the molecule.

No study of this type performed so far has revealed any evidence of risk associated with the CP4 EPSPS present in the Roundup Ready® soybeans. These results have been amply supported by experimental data of diverse types (Burks and Fuchs 1995, Fuchs and Astwood 1996, Chang et al. 2003, Sten et al. 2004).

\section{RESULTS FROM THE USE OF THE} FARRP DATABANK

To supplement previous studies, we have used the allergen databank from FARRP (Food Allergy Research and Resource Program: http://www.allergenonline.com), which consists of 658 single entries of allergens known from a diversity of origins. A search in this databank using the amino acid sequence of CP4 EPSPS as the probe, utilizing the FASTA program and a maximum E-value of 30 (Pearson 2000) showed that no known allergy presented significant similarity with the enzyme CP4 EPSPS. The results followed what was expected for random alignments between unrelated sequences. In addition to this, none of the resulting 73 align- ments presented any stretch of six contiguous identical residues. We can conclude that, coherently with previous results and within the limitations of the present theoretical methodologies, there is no evidence of any risk of allergenicity resulting from the expression of CP4 EPSPS in the Roundup Ready® soybeans.

\section{COMments on Structure AND Allergenicity}

Aalberse (2000), in a recent survey, commented that the majority of allergenic proteins for which three-dimensional structures are known can be classified into one of four dominant structural classes. These are: (1) dominated by anti-parallel $\beta$-sheets; (2) anti-parallel $\beta$-sheets associated with one or more $\alpha$-helices; (3) structures of the type $\alpha+\beta$; and (4) $\alpha$-proteins. EPSPS does not belong to any of these classes, since it has an unusual type of curling, the "inside-out $\alpha / \beta$ barrel". Also, among the closest relatives in the CATH structural classification tree, no known allergen is found.

\section{BIOSAFETY OF ROUNDUP READY® SOYBEANS}

Scientific organizations around the world agree that foods derived from GMOs are not inherently less safe that conventional foods (FAO/WHO 2000, OECD 2000, Scientific Societies 2000). However, it is very clear that individuals and countries expect that foods should be safe and not cause harm if stored and prepared correctly (Robinson 2001). As with all natural products, there are risks associated with any food, whether derived from a GMO or not. For example, there is the possibility that some harmful agent present in the food could cause some adverse effect, as is the case of toxins in canned foods or foods that are not conserved at the appropriate temperature. In the same way, many individuals are allergic to soybeans, eggs or peanuts developed in the traditional manner. Thus, various independent international bodies have, in the best manner possible, sought to develop mechanisms to ensure the safety of foods derived from GMOs (FAO/WHO 2000, OECD 2000, Lajolo and Nutti 2003). 
The basic principle for establishing how safe a new food is based on the substantial equivalence between the foods obtained from the GMO and the plant from which it has been derived (conventional plant). The central idea is that: "The transgenic food must be as safe as what gave rise to it", considering the intended use and intentional and unintentional modifications (Lajolo and Nutti 2003, p.29).

Two points deserve special clarification before we enter specifically into the case of Roundup Ready® soybeans. First, the demonstration of substantial equivalence between plants is based on exhaustive tests for demonstrating agronomical, chemical and nutritional equivalence (which is the case of the present discussion). Even though there is no single methodology for determining substantial equivalence, there are recommendations for the utilization of specific tests and for performing studies to refine the methodology (reviewed by Robinson 2001, Lajolo and Nutti 2003). Second, the demonstration of substantial equivalence is only the first step in determining the food safety. There must also be an evaluation of the consequences of expressing the transgene on the metabolism of the organism as a whole and, especially, the toxicity and allergenicity of the transgene, while always considering the way in which it is utilized in the food chain. It is therefore clear that demonstrating the food safety of a food derived from a GMO is based on scientific experimentation and is followed up by various independent international bodies like the World Health Organization (WHO), Organization for Economic Cooperation and Development (OECD, see bibliographic reference), International Food Information Council (IFIC) and governmental organizations from different countries (Robinson 2001). In Brazil, the National Council for Biosafety (CTNBio) was created in 1995 (Law No. 8.974, modified by Provisional Measure No. 2.191-9 of 2001). At present, CTNBio is the collegiate reference point that provides consultative and advisory technical support, establishes technical safety norms and issues opinions relating to foods derived from GMOs.

The characterization of the event of introduc- ing the cp4 epsps gene into soybeans and the characterization of the protein 5-enolpyruvylshikimate3-phosphate synthase (EPSPS) of the CP4 strain of Agrobacterium sp. that is present in the Roundup Ready® soybeans have been described above. It is emphasized that the chemical structure of the deoxyribonucleic acid (DNA) inserted into the Roundup Ready® soybeans is equivalent to the existing DNA in soybeans themselves, to the DNA in other substances that we consume or to our own DNA. The intake of DNA that is foreign to an individual's genome has already been occurring since the beginning of the process of evolution of the species. Thus, the chances that a fragment of transgenic DNA present in a food derived from a GMO might aggregate with the DNA of the intestinal microbiota or of our cells is insignificant, when compared with the quantity of DNA that we intake every day. Moreover, the body deals with all DNA in the same way, whether it is transgenic or genomic (Jonas et al. 2001).

However, even if there is a desire to discuss the presence of transgenic DNA in foods within the topic of food safety, the kinetics of degradation during the process of industrialization of the food have to be considered. Studies using the DNA of Roundup Ready® soybeans have demonstrated the extremely low likelihood of finding the CP4 EPSPS protein in the blood, milk or feces of animals (Phipps et al. 2003). It is therefore clear that it is the protein coded by the DNA, and not the DNA per se, that must be considered in assessment studies on the possible risks in terms of toxicity, allergenicity and alteration of the nutritional value of a food derived from a GMO (Robinson 2001). We will deal with this after describing the studies that have demonstrated the chemical and nutritional equivalence between Roundup Ready® soybeans and traditional soybeans.

\section{CHEMICAL AND NUTRITIONAL EQUIVALENCE}

The analytical efforts for evaluating the composition of the Roundup Ready® soybeans in relation 
to traditional cultivars have been enormous. More than 1,700 individual analyses on different forms of the product have been made (grains, roasted defatted soybean bran, non-roasted defatted soybean bran, refined soybean oil and soybean lecithin) (Padgette et al. 1995, 1996b, List et al. 1999, Taylor et al. 1999). In these latter studies, an appropriate experimental delineation was performed, respecting the planting out in random blocks, with analysis per sample, for each planting location (Lajolo and Nutti 2003).

Bromatological studies with analysis of percentages (protein, fat, fiber, ash, carbohydrate and moisture) and of amino acid composition (including aromatic amino acids) in six locations in the United States in 1992 and four locations in 1993 demonstrated the similarity between Roundup Ready ${ }^{\circledR}$ soybeans and traditional cultivars (in the case of the non-transformed parental lineage A5403) (Padgette et al. 1996b, Taylor et al. 1999). In the same way, the quantities of isoflavones (or phytoestrogens), including genistein and daidzein, and of antinutrients like the trypsin inhibitor, were similar between the Roundup Ready® soybeans and the control soybeans (Padgette et al. 1996b, Taylor et al. 1999). Finally, the composition of the phospholipids (lecithin, phosphatidylcholine, phosphatidylethanolamine, phosphatidylinositol and phosphatidic acid) was no different between the Roundup Ready® and conventional soybeans (List et al. 1999). These studies demonstrate that there is a substantial equivalence between Roundup Ready ${ }^{\circledR}$ soybeans and traditional cultivars, from the point of view of chemical composition, both in unprocessed and macerated fractions.

Studies assessing the acute nutritional value (around four weeks) or chronic nutritional value (up to 15 weeks) have already be carried out using rats, mice, pigs, chicken, fish, nothura and cattle (Hammond et al. 1996, Rogers 1998, Cromwell et al. 2001, Teshima et al. 2000). These studies demonstrate that feeding with Roundup Ready® soybeans was substantially equivalent to feeding with traditional soybeans for inducing growth in the animals and the production of milk and fermentation of the cows' rumen. It is also emphasized that the quantity of Roundup Ready® soybeans utilized was at least 100 times greater than what is usually consumed by the population or domesticated animals. In 15-week studies on mice and rats, the utilization of Roundup Ready® soybeans did not induce modification of the immune organs or the levels of immunoglobulin (antibodies) in the animals treated. The Roundup Ready® and conventional soybeans varieties were similar in their capacity to induce growth in the animals (Teshima et al. 2000).

It is therefore concluded that there is chemical and nutritional equivalence between Roundup Ready ${ }^{\circledR}$ soybeans and traditional cultivars. The difference that there is between the transgenic and traditional species is the existence of the protein $\mathrm{CP} 4$ EPSPS in the Roundup Ready® soybeans.

\section{TOXICOLOGY}

As described above, the EPSPS enzyme belongs to a family of proteins that exist naturally and which are frequently part of our diet (derived from plants and microorganisms). On the basis of the quantities of the protein CP4 EPSPS in various transgenic cultivars, it has been estimated that this protein represents only $0.08 \%$ of the total protein present in soybeans (Padgette et al. 1995, Taylor et al. 1999). In addition to this, the protein is rapidly destroyed in digestive systems in vitro (Harrison et al. 1996). This has important toxicological and allergenic implications, since it is improbable that a protein that is rapidly digested could maintain its toxicity and allergenicity in vivo (Astwood et al. 1996).

As mentioned earlier, chronic administering of Roundup Ready® soybeans (15 weeks) to rats and mice did not result in functional or structural alterations to the organs of the immune system and did not show signs of liver poisoning (Teshima et al. 2000). Also, rats fed for periods of five months with a protein concentrate derived from Roundup Ready® or conventional soybeans did not show significant alterations in the cell membrane functions 
or enzymatic system activity involved in the detoxification of endotoxic or exotoxic compounds (Tuteljan et al. 1999).

In independent experiments, the protein $\mathrm{CP} 4$ EPSPS was administered to mice at doses of 572 $\mathrm{mg} / \mathrm{kg}$ of weight, and the acute toxic effects were evaluated. This dose is at least 1,300 times greater than the dose that might potentially be taken by man, which would only be obtained if CP4 EPSPS were also expressed in maize, tomatoes and potatoes, and without considering the degradation of the protein before human consumption. No acute adverse effect was observed in the animals treated (Harrison et al. 1996). Thus, the studies carried out to evaluate the administering of appreciable quantities of the protein CP4 EPSPS or of Roundup Ready ${ }^{\circledR}$ soybeans have demonstrated that there is no acute or chronic toxic effect detectable. These numbers are even more significant if we consider that the greatest quantity of soybeans present in the food chain is found in the form of processed food, in which the protein CP4 EPSPS is in a denatured state.

\section{ALLERGENICITY}

There is no consensus regarding the best way of assessing the risk that a protein or food derived from a GMO might induce allergenicity in human beings, and this is a field that has continually been modified over the course of the years, always seeking the best way of guaranteeing food safety (Nestle 1996, Robinson 2001, FAO/WHO 2001, Lajolo and Nutti 2003). Study of some characteristics of the protein introduced into the genetically modified food appears to be useful for predicting its allergenic character. Thus, a protein has a greater chance of being allergenic if it is similar to known allergens, it remains stable when processed or digested, or it has high prevalence in the food in question. The presence of the above characteristics in a protein should cause concern about its use, not because of the real risk of allergenicity, but because of the possibility (even if remote) that this could occur.
With regard to its structural characteristics and similarity with the structure of known allergens, the risk that the protein CP4 EPSPS might be allergenic was discussed in the preceding chapter. As was described, the protein CP4 EPSPS of the Roundup Ready ${ }^{\circledR}$ soybeans does not have any structural similarity or sequence similarity with known allergens. In addition to this, the protein CP4 EPSPS presents low stability and is rapidly destroyed by processing or by digestive enzymes (Harrison et al. 1996). In studies carried out using experimental animals, administering Roundup Ready® soybeans or traditional cultivars did not induce measurable quantities of antibodies of $\operatorname{IgE}$ type (which are associated with allergies), against soybean proteins (Teshima et al. 2000). Finally, in studies using serum from patients who were recognized to be allergic to traditional soybeans, the allergenic potential was not altered by the presence of the transgene (Burks and Fuchs 1995, Sten et al. 2004). In the same way, the cutaneous response of patients known to allergic was also not altered by the presence of the protein EPSPS (Sten et al. 2004). Together, these studies suggest that the consumption of Roundup Ready® soybeans containing the protein CP4 EPSPS does not appear to modify the allergenicity of the traditional soybeans. In short, patients who are allergic to conventional soybeans will necessarily be allergic to Roundup Ready® soybeans. On the other hand, the scientific data available suggest that patients who are not allergic to conventional soybeans do not develop any allergy by consuming Roundup Ready® soybeans.

In conclusion, there are many scientific studies published in international scientific journals with respectable editorial boards. These articles are accessible through searching websites like PubMed (search site for scientific articles published in journals with editorial boards in the biomedical field) and the CAPES portal (Commission for Improvement of Personnel in Higher Education, of the Ministry of Education). A careful evaluation of these articles demonstrates that there is substantial equivalence between Roundup Ready® soybeans and 
traditional cultivars, when the chemical, toxicological and nutritional parameters are assessed. In addition to this, there are published studies demonstrating that the protein CP4 EPSPS of the Roundup Ready® soybeans does not present any detectable toxicological effect or allergenicity, and that they do not present new food risk. It is therefore concluded that the data in the literature suggest that the Roundup Ready® soybeans are substantially equivalent and therefore present food safety similar to that of cultivars of traditional soybeans.

\section{CLOSING REMARKS}

This review presents a body of experimental data, the vast majority available before September 1998, that were the fundamental basis for the Brazilian National Council for Biosafety to consider Roundup Ready® soybean safe for the environment and for human and animal consumption. It is critical to keep in mind that, as defined by law, the sole duty of that board is to consider aspects related to biosafety of a GMO or its derivatives. The judicial battle that began thereafter was clearly and, unfortunately, contaminated by ideological, political, and economic aspects brought up by those representing opposition to the technology of transgenes. Strategic aspects based on political and economical impacts of new technologies are relevant and must be discussed by appropriated bodies. What it is not appropriated is that scientifically sound data are misquoted and used as arguments to support non scientific issues. In this regard, the scientific community should stand behind science and provide society with reliable information in order to contribute to an accurate perception for the reason to accept or not to accept a given GMO. A GMO or its derivative is neither safe a priori nor is it unsafe because it is a GMO. It must be discussed on a case-by-case basis. Spreading of misleading information can only disturb the society and its capacity to decide the best route that will ensure a sustained development that can reach those in greater need for benefits derived from leading edge technological achievements. Taken the exam- ple of soybean, we should be better prepared and more critical in filtering information that shall be the basis for deciding the future of upcoming GMOs and their derivatives.

\section{ACKNOWLEDGMENTS}

This review was written using material prepared by a group of scientists as part of a larger project with financial support from Monsanto Brazil. The Authors declare no conflict of interest as regard to financial benefits from marketing of Roundup Ready® Soybeans and are not stock shares holders from Monsanto. The content and conclusions presented herein are the sole responsibility of the authors and do not necessarily reflect the opinions of their institutions.

\section{RESUMO}

A biosegurança dos organismos geneticamente modificados e seus derivados é um dos principais tópicos na agenda de discussões de governos e sociedades. O objetivo desta revisão é reviver os dados científicos que fundamentaram a decisão de liberação comercial da soja transgênica resistente ao Glifosate com o intuito de estimular uma posição crítica da comunidade científica para as próximas discussões no tema. A soja em questão é apenas um exemplo de como a biotecnologia pode contribuir para avanços na produtividade e na preservação do meio ambiente, com ganho de produtividade e lucratividade para agricultores em todas as escalas. Novas variedades trangênicas estarão na pauta de discussões que deverão estar fundamentadas em dados científicos objetivos, evitando argumentos emocionais que poderão, assim como no passado recente, prejudicar o desenvolvimento científico e tecnológico da agricultura.

Palavras-chave: biosegurança, organismos geneticamente modificados, transgênico.

\section{REFERENCES}

AGi - Arabidopsis Genome Initiative. 2000. Analysis of the genome sequence of the flowering plant Arabidopsis thaliana. Nature 408: 796-815. 
AALBERSE RC. 2000. Structural biology of allergens. J Allergy Clin Immunol 106: 228-238.

Ahrent DK And CAVIness CE. 1994. Natural crosspollination of twelve soybean cultivars in Arkansas. Crop Sci 34: 376-378.

ANDERSON JA. 1996. Allergic reactions to foods. Crit Rev Food Sci Nutr 36 (Suppl): S19-38.

Astwood JD, LEACH JN AND FuCHS RL. 1996. Stability of food allergens to digestion in vitro. Nat Biotechnol 14: 1269-1273.

BARRY GG ET AL. 1992. Inhibitors of amino acid biosynthesis: Strategies for imparting glyphosate tolerance to crop plants. In: SINGH BK, FLORES HE AND SHANNON JC (Eds), Biosynthesis and molecular regulation of amino acids in plants. Rockville: American Society Plant Physiologists, p. 139-145.

BECKER WM. 2001. Topic 4: Sequence homology and allergen structure. In: Working Paper Biotech 01/06 for the Joint FAO/WHO Expert Consultation on Allergenicity of Foods Derived from Biotechnology, Jan 22-25, Rome, Italy.

BENTLEY R. 1990. The shikimate pathway-a metabolic tree with many branches. Crit Rev Biochem Mol Biol 25: 307-384.

BURKS AW AND FUCHS RL. 1995. Assessment of the endogenous allergens in glyphosate-tolerant and commercial soybean varieties. J Allergy Clin Immunol 96: 1008-1010.

CARLson JB AND LERSTEN NR. 1987. Reproductive morphology. In: WILCOX JR (Eds), Soybeans: improvement, production and uses. $2^{\text {nd }}$ ed., Madison: American Society of Agronomy, p. 95-134.

CAVINESS CE. 1970. The indispensable pollinators. University of Arkansas Extension. Arkansas: Service Publication Fayetteville, Cross-pollination in the soybeans, p. 33-36.

CAVINESS CE. 1996. Estimates of natural cross-pollination in Jackson soybeans in Arkansas. Crop Sci 15: $84-86$.

Chang HS et AL. 2003. The 5-enolpyruvylshikimate3-phosphate synthase of glyphosate-tolerant soybean expressed in Escherichia coli shows no severe allergenicity. Mol Cells 15: 20-26.

Chen SW And Pellequer JL. 2004. Identification of functionally important residues in proteins using comparative models. Curr Med Chem 11: 595-605.
Cromwell GL et AL. 2001. Soybean meal from Roundup Ready® or conventional soybeans in diets for growing-finishing pigs. J Anim Sci 79: S318319.

Duke SO. 1988. Herbicides. In: Kearney PC, KaufFMan DD, Marcel DeKKer DD (Eds), Chemistry degradation and mode of action. New York, Crown Pu Group.

FAO/WHO. 2000. Safety aspects of genetically modified foods of plant origin: report of a joint FAO/WHO expert consultation on foods derived from biotechnology. Geneva, WHO Food Safety Programme.

FAO/WHO. 2001. Evaluation of allergenicity of genetically modified foods. Report of a joint FAO/WHO expert consultation on allergenicity of foods derived from biotechnology. Geneva, WHO Food Safety Programme.

Fuchs RL AND Astwood JD. 1996. Allergenicity assessment of foods derived from genetically modified plants. Food Technol 50: 83-88.

Goldsmith-Fischman S AND Honig B. 2003. Structural genomics: computational methods for structure analysis. Protein Sci 12: 1813-1821.

GRUYS KJ, WALKER MC AND SIKORSKI JA. 1992. Substrate synergism and the steady-state kinetic reaction mechanism for EPSP synthase from Escherichia coli. Biochemistry 31: 5534-5544.

Gruys KJ, Marzabadi MR, Pensagrau PD and SIKORSKI JA. 1993. Steady-state kinetic evaluation of the reverse reaction for Escherichia coli 5enolpyruvylshikimate-3-phosphate synthase. Arch Biochem Biophys 304: 345-351.

HAMMOND BG ET AL. 1996. The feeding value of soybeans fed to rats, chickens, catfish and dairy cattle is not altered by genetic incorporation of glyphosate tolerance. J Nutr 126: 717-727.

HARRISON LA ET AL. 1996. The expressed protein in glyphosate-tolerant soybean, 5-enolpyruvylshikimate-3-phosphate synthase from Agrobacterium sp. strain $\mathrm{CP} 4$, is rapidly digested in vitro and is not toxic to acutely gavaged mice. J Nutr 126: 728-740.

Hymowitz T. 1970. Speciation and Cytogenetics. In: BOERMA HR AND SPECHT JE (Eds), Soybeans: Improvement, Production and Uses. Agronomy No. 16. American Society of Agronomy. 
JAMES C. 2002. Global status of commercialized transgenic crops.

<URL:http://www.isaaa.org/Press_release/ Briefs30-2003/es_b30.pdf> [2004, Nov 11].

JefFerson RA, Klass M, WOLF N AND Hirsh D. 1987. Expression of chimeric genes in Caenorhabditis elegans. J Mol Biol 193: 41-46.

JONAS DA ET AL. 2001. Safety considerations of DNA in food. Ann Nutr Metab 45: 1-20.

KegG - Kyoto EnCyClopedia of Genes AND GENOMES. <URL:http://www.genome.[jp/kegg> 2004, Nov 20].

Kim DH, Tucker-KellogG GW, LeEs WJ AND WALSH CT. 1996. Analysis of fluoromethyl group chirality establishes a common stereochemical course for the enolpyruvyl transfers catalyzed by EPSP synthase and UDP-GlcNAc enolpyruvyl transferase. Biochemistry 35: 5435-5440.

KIRKWOOD J. 2002. Cancer immunotherapy: the interferon-alpha experience. Semin Oncol 29 (Suppl 7): $18-26$.

Kishore GM AND SHAH DM. 1988. Amino acid biosynthesis inhibitors as herbicides. Annu Rev Biochem 57: 627-663.

Kopp J And Schwede T. 2004. Automated protein structure homology modeling: a progress report. Pharmacogenomics 5: 405-416.

LACKey JA. 1981. Phaseolae. In: Polhill RM AND RAVEN PH (Eds), Advances in legume systematics. England: Royal Botanic Gardens Kew, p. 301-327.

LAJOlo FM AND NutTi MR. 2003. Transgênicos: bases científicas da sua segurança. São Paulo: Brazilian Society of Feeding and Nutrition.

LeVitT M AND Chothia C. 1976. Structural patterns in globular proteins. Nature 261: 552-557.

List GR, ORTHOEFER F, TAYLOR N, NELSON T AND ABIDI SL. 1999. Characterization of phospholipids from glyphosate-tolerant soybeans. JAOCS 76: 5760.

McDowell LM, Klug CA, Beusen DD AND SCHAEFER J. 1996a. Ligand geometry of the ternary complex of 5-enolpyruvylshikimate-3-phosphate synthase from rotational-echo double-resonance NMR. Biochemistry 35: 5395-5403.

McDowell LM, Schmidt A, Cohen ER, STUdel-
SKA DR AND SCHAEFER J. 1996b. Structural constraints on the ternary complex of 5-enolpyruvylshikimate-3-phosphate synthase from rotational-echo double-resonance NMR. J Mol Biol 256: 160-171.

MCGREGOR SE. 1976. Insect pollination of cultivated crop plants. Washington DC: US Department of Agriculture (Agricultural Handbook No. 496).

MEKORI YA. 1996. Introduction to allergic diseases. Crit Rev Food Sci Nutr 36 (Suppl): S1-18.

Metcalfe DD, Astwood JD, Townsend R, SAMPSON HA, TAYLOR SL AND FUCHS RL. 1996. Assessment of the allergenic potential of foods derived from genetically engineered crop plants. Crit Rev Food Sci Nutr 36 (Suppl): S165-186.

Murzin AG, Brenner SE, Hubbard T ANd CHoTHIA C. 1995. SCOP: a structural classification of proteins database for the investigation of sequences and structures. J Mol Biol 247: 536-540.

NeSTLE M. 1996. Allergies to transgenic foods - questions of policy [Editorial]. N Engl J Med 334: 726728.

OECD - ORGANIZATION FOR ECONOMIC COOPERATion And Development. 2000. Report of the task force for the safety of novel foods and feeds. OECD/OCDE Report. Paris: Organization for Economic Cooperation and Development.

Orengo CA, Michie AD, Jones S, Jones DT, SWINDELLS MB AND THORNTON JM. 1997. CATH - A Hierarchic Classification of Protein Domain Structures. Structure 5: 1093-1108.

PADGETTE SR ET AL. 1991. Site-directed mutagenesis of a conserved region of the 5-enolpyruvylshikimate3-phosphate synthase active site. J Biol Chem 266: 22364-22369.

PADGETTE SR ET AL. 1995. Development, identification and characterization of a glyphosate-tolerant soybean line. Crop Sci 35: 1451-1461.

PADGETTE SR ET AL. 1996a. New weed control opportunities: development of soybeans with a Roundup Ready® gene. Herbicide-Resistant Crops, p. 53-84.

Padgette SR ET AL. 1996b. The composition of glyphosate-tolerant soybean seeds is equivalent to that of conventional soybeans. J Nutr 126: 702-716.

PEARSON WR. 2000. Flexible sequence similarity searching with the FASTA3 program package. Methods Mol Biol 132: 185-219. 
Phipps RH, Deaville ER And Maddison C. 2003. Detection of transgenic and endogenous plant DNA in rumen fluid, duodenal digest, milk, blood and feces of lactating dairy cows. J Dairy Sci 86: 4070-4078.

ROBERTS F ET AL. 1998. Evidence for the shikimate pathway in apicomplexan parasites. Nature 393: 801-805.

ROBINSON C. 2001. Genetic modification technology and food: consumer health and safety. Brussels: ILSI Europe, ILSI Press.

RogAN GJ, DUdin YA AND LEE TC. 1999. Immunodiagnostic methods for detection of 5-enolpyruvylshikimate-3-phosphate synthase in Roundup Ready® soybeans. Food Control 10: 407-414.

RogERS SG. 1998. Biotechnology and the soybean. Am J Clin Nutr 68 (Suppl): S1330-1332.

Ruff TD, Eichholtz D, Re S, Padgette G, KISHORE GM. 1991. Effects of amino acid substitutions on glyphosate tolerance and activity of EPSPS. Plant Physiol 96 (Suppl): 94.

SAli A AND Blundell TL. 1993. Comparative protein modelling by satisfaction of spatial restraints. J Mol Biol 234: 779-815.

SAMPSON HA AND BURKS AW. 1996. Mechanisms of food allergy. Annu Rev Nutr 16: 161-177.

SCHÖNBRUNN E ET AL. 2001. Interaction of the herbicide glyphosate with its target enzyme 5-enolpyruvylshikimate-3-phosphate synthase in atomic detail. Proc Natl Acad Sci USA 98: 1376-1380.

SCIENTIFIC Societies. 2000. Transgenic plants and world agriculture. Joint report of the Science academies from Brazil, China, India, Mexico, United States, the Third World Academy of Sciences and the UK Royal Society. London: The Royal Society.

SHOEMAKER RC ET AL. 1996. Genome duplication in soybean (Glycine subgenus soja). Genetics 144: 329-338.

STALLINGS WC ET AL. 1991. Structure and topological symmetry of the glyphosate target 5-enolpyruvylshikimate-3-phosphate synthase: a distinctive protein fold. Proc Natl Acad Sci USA 88: 5046-5050.
STEINRUCKEN HC AND AMrhein N. 1980. The herbicide glyphosate is a potent inhibitor of 5-enolpyruvylshikimic acid-3-phosphate synthase. Biochem Biophys Res Commun 94: 1207-1212.

STEN E ET AL. 2004. A comparative study of the allergenic potency of wild-type and glyphosate-tolerant gene-modified soybean cultivars. APMIS 112: 2128.

TAYLOR NB, Fuchs RL, MACDONALD J, SharifF A And Padgette S. 1999. Compositional analysis of glyphosate-tolerant soybeans treated with glyphosate. J Agric Food Chem 47: 4469-4473.

Teshima R ET AL. 2000. Effect of GM and non-GM soybeans on the immune system of $\mathrm{BN}$ rats and $\mathrm{B} 10 \mathrm{~A}$ mice. J Food Hyg Soc Japan 41: 188-193.

Tuteluan VA ET AL. 1999. Safety assessment of protein concentrate derived from genetically modified soybean, line 40-3-2 effect on some biochemical parameters. Voprosy Pitaniya 68: 9-12.

VAn Heijenoort J, Ghutsen JM AND HaCKenBECK R. 1994. Bacterial cell wall. Amsterdam: Elsevier Science Pu BV, p. 39-54.

Walsh CT, Benson TE, Kim DH And Lees WJ. 1996. The versatility of phosphoenolpyruvate and its vinyl ether products in biosynthesis. Chem Biol 3: 83-91.

Williams GM, Kroes R AND Munro IC. 2000. Safety evaluation and risk assessment of the herbicide Roundup and its active ingredient glyphosate for humans. Regul Toxicol Pharmacol 31: 117-165.

Windels P, TAVERniers I, DePICKer A, VAN Bockstaele E And De Loose M. 2001. Characterization of the Roundup Ready® soybean insert. Eur Food Res Technol 213: 107-112.

Woodworth CM. 1922. The extent of natural crosspollination in soybeans. J Am Soc Agronomy 14: 278-283.

WORLD POPULATION TO 2300. <URL:http://www.un.org/esa/population/ publications/longrange2/WorldPop2300fina1.pdf > [2004, Oct 20]. 